\title{
SOSIOLEK DALAM NOVEL MEGAMENDUNG KEMBAR \\ KARYA RETNI S.B
}

(Kajian Sosiolinguistik)

\author{
Muhammad Dwiki Saputra \\ Universitas Pamulang \\ dwikisaputra9@gmail.com
}

\begin{abstract}
ABSTRAK
Dialek sosial atau sosiolek merupakan suatu perwujudan dari identitas yang dimiliki orang lain atau kelompok. Dialek sosial atau sosiolek juga memiliki sensitivitas yang tinggi karena, dialek sosial ini menyangkut dengan tingkat ekonomi seseorang, kebangsawanaan, profesi dan kelas sosial seseorang di masyarakat. Penelitian ini bertujuan untuk mendeskripsikan bentuk lingual dialek sosial atau sosiolek yang ada dalam novel Megamendung Kembar karya Retni S.B, selain itu penelitian ini juga bertujuan untuk mendeskripsikan fungsi sosiolek yang ada dalam novel Megamendung Kembar karya Retni S.B. Penelitian ini menggunakan metode simak, dengan teknik baca, deskripsi, kutip dan pengklasifikasian. Hasil penelitian ini menunjukkan bentuk-bentuk lingual dialek sosial atau sosiolek yang ada dalam novel Megamendung Kembar karya Retni S.B dengan jumlah 10 data dalam bentuk kata, 10 data dalam bentuk frasa dan 10 data dalam bentuk klausa, selanjutnya hasil lainnya berupa data fungsi informatif yang berjumlah 3 data, fungsi ekspresif yang berjumlah 3 data dan fungsi direktif yang berupa 3 data.

Kata Kunci: Sosiolinguistik, Variasi Bahasa, Sosiolek
\end{abstract}

\section{PENDAHULUAN}

Bahasa merupakan suatu alat yang digunakan oleh manusia sebagai alat untuk berkomunikasi antara sesamanya. Chaer dan Agustina (2010:11) mengatakan bahwasannya, bahasa adalah sebuah sistem lambang, berupa bunyi, bersifat arbitrer, produktif, dinamis, beragam, dan manusiawi. Bahasa juga dibentuk dari sejumlah komponen yang berpola secara tetap dan dapat dikaidahkan. Bahasa selain bersifat sistematis juga bersifat sistemis. Yang dimaksud dengan sistemis adalah bahasa tersusun menurut suatu pola tertentu tidak tersusun secara acak atau sembarangan. Sedangkan sistematis yaitu, berurutan dari awal hingga akhir tidak terbalik. Mengikuti kaidah-kaidah kebahasaan yang berlaku. Bila berbicara mengenai suatu bahasa tentu bahasa tidak akan terlepas dari fungsi sosialnya selain sebagai alat komunikasi, bahasa juga memiliki peran penting dalam masyarakat dan bahasa juga memiliki cabang keilmuannya masing-masing. Salah satunya yaitu Sosiolingustik. Holmes dalam Warisman (2014:5) memberikan suatu batasan pada pengertian kompetensi sosiolinguistik sebagai suatu pengetahuan yang mendasari kemampuan manusia dalam menggunakan bahasa yang dimilikinya secara tepat. Kemampuan ini berkaitan dengan kaidah-kaidah yang ada pada sosiokultural serta kaidah-kaidah yang ada dalah suatu wacana. Dalam penggunaan bahasa, suatu kelompok melahirkan suatu sosiolek atau dialek sosial yang hanya dimengerti oleh individu-individu yang terikat dengan kelompok sosialnya, sehingga dialek sosial tersebut takkan bisa dimengerti oleh kelompok lain kecuali kelompok atau individu tersebut mau mempelajari mengenai dialek sosial yang ada pada kelompok lain. Lapasau dan Arifin (2016: 179) berpendapat, seseorang atau suatu kelompok menggunakan variasi bahasa sebagai bentuk dari identitas orang atau kelompok tersebut sehingga variasi bahasa yang digunakan bisa menjadi lambang dari identitas orang atau kelompok tersebut, menggunakan bahasa sebagai variasi bahasa yang hanya dapat dimengerti oleh orang-orang yang berkesinambung di dalam kelompok tersebut. Senada dengan variasi bahasa yang ada pada novel Megamendung Kembar karya Retni S.B. Variasi 
bahasa yang digunakan tersebut salah satunya adalah variasi bahasa sosiolek. Berkaitan dengan permasalahan yang akan penulis lakukan pada penelitian ini . penulis memiliki dua rumusa masalah yaitu , Bagaimana bentuk lingual sosiolek yang ada dalam novel Megamendung Kembar Karya Retni S.B dan Bagaimana fungsi sosiolek pada tokoh-tokoh yang terlibat dalam novel Megamendung Kembar karya Retni S.B. Selain itu penulis juga memiliki tujuan dalam melakukan penelitian ini diantaranya Mendeskripsikan dan menunjukan bentuk lingual sosiolek dalam novel Megamendung Kembar karya Retni S.B. Mendeskripsikan fungsi sosiolek pada tokoh-tokoh yang ada dalam novel Megamendung Kembar karya Retni S.B. Penulis berharap penelitian ini dapat menjadi refrensi bagi orang-orang yang meneliti hal terkait seperti yang penulis sedang lakukan, adapun kegunaan penelitian ini diantaranya, mengetahui arti dan makna sosiolek yang ada pada kelompok sosial yang ada dalam masyarakat, menambah pengetahuan bahasa dan pengetahuan mengenai sosiolinguistik.

\section{TEORI DAN METODOLOGI}

Hartman dan Stork dalam Chaer dan Agustina (2010:62) menyatakan pendapatnya bahwa variasi bahasa dibagi menjadi beberapa bagian seperti; latar belakang geografi, sosial penutur, medium yang digunakan dan pokok pembicaraan. Halliday dalam Chaer dan Agustina (2010:62) juga menjelaskan bahwa variasi bahasa dapat dibedakan berdasarkan, pemakai yang disebut dialek dan pemakai yang disebut register. Dari kedua pendapat di atas dapat diketahui bahwasannya menurut Hartman dan Stork latar belakang geografis, kedudukan sosial, medium yang digunakan serta substansi pembicaraan mempengaruhi tuturan dalam berbahasa, sedangkan menurut pendapat yang kedua menurut Halliday variasi bahasa dibedakan berdasarkan pemakai dialek dan pemakai register. Pemakai dialek berarti orang yang secara objek nyata tuturannya melantunkan dialek yang ada, sedangkan pemakai register adalah hal yang tertuang di dalam sebuah tulisan. Dalam menganalisis variasa bahasa yang pertama kali harus dilakukan ialah, membedakan antara penutur dan penggunannya. Berdasarkan penutur berarti, siapa orang yang menggunakan bahasa itu, tempat tinggalnya, bagaimana kedudukan sosial orang tersebut, dan kapan bahasa tersebut digunakan. Salah satu variasi bahasa berdasarkan penuturnya yaitu dialek sosial atau sosiolek. Sosiolek, atau dialek sosial adalah salah satu variasi bahasa yang bersinggungan dengan, status, golongan dan kelas sosial pada penuturnya (Chaer dan Agustina, 2010:64). Pada kajian sosiolinguistik sering kali variasi bahasa ini yang sering menjadi bahan perbincangan. Karena variasi bahasa yang satu ini langsung menyinggung semua permaslahan yang ada pada penuturnya sepetri, pekerjaan, pendidikan, seks, tingkat kebangsawanan, keadaan ekonomi, keadaan sosial dan hal-hal sejenisnya. Sebagai salah satu contoh, coba perhatikan variasi bahasa yang ada pada remaja, orang dewasa dan lanjut usia. Perbedaan yang ada pada variasi bahasa ini bukan berdasarkan pada substansi pembicaraanya akan tetapi pada pemilihan kosa kata dan permainan diksinya. Perbedaan pekerjaan dan profesi juga dapat menyebabkan terjadinya variasi sosial. Bila diperhatikan, penggunaan bahasa para buruh, pedagang kecil, tukang, pengemudi kendaraan umum, mubalig dan para pengusaha akan berebeda, variasi bahasa yang diujarkan pada orang-orang yang menggeluti profesi di atas, secara tidak langsung akan menggambarkan posisi masing-masing di masyarkat. Antara si pedagang kecil dengan seorang pengusaha akan sangat terlihat sekali jaraknya dalam menggunakan variasi bahasa ini. 
Karenanya, kembali pada pendapat di atas variasi bahasa yang satu ini selain sering menjadi perbincangan, juga mempunyai tingkat sensitivitas yang cukup tinggi.

Bentuk dan strategi penelitian ini terarah kepada penelitian kualitatif yang bersifat deskriptif. penelitian ini mengarah pada pendeskripsian secara rinci dan mendalam mengenai hal-hal yang ditemukan dalam sasaran penelitian. Denzin dan Lincoln dalam Anggito dan Setiawan (2018:7) memberikan pendapat bahwasannya penelitian kualitatif adalah penelitian yang menggunakan latar alamiah, dengan maksud menafsirkan fenomena, yang terjadi dan dilakukan dengan jalan melibatkan berbagai metode yang ada. Penelitian kualitatif tidak menggunakan data statistik, tetapi melalui pengumpulan data, analisis, kemudian diintepretasikan. Biasanya berhubungan dengan masalah sosial dan manusia yang bersifat interdisipliner, fokus pada multimetod, naturalistik dan interpretatif dalam pengumpulan data. Penulis menggunakan metode kualitatif karena data yang akan dibahas berupa data yang hanya dibahasakan, bukan berupa rumus statistik ataupun dalam jumlah angka, data yang akan penulis sajikan berupa penjabaran yang bersumber dari setiap peristiwa yang ada dalam novel yang akan dikutip dan dideskripsikan dengan argumen dan analisis penulis.

\section{TEMUAN DAN PEMBAHASAN}

Penulis menjabarkan bentuk lingual yang ada pada novel Megamendung Kembar karya Retni S.B. Data itu berupa kata, frasa, klausa. Penulis mengklasifikasikan ke dalam bentuk deskripsi dan memberi masingmasing sub untuk penjabaran datanya. Berikut salah satu sub pembahasan penulis yang berupa kata.

\section{KATA}

Data 01

“Aih, biaaang, Mbak... Mbak... lagi akting tah apa jeh. Sida bli kih numpak beca e?”(MK:23)

Berdasarkan kutipan di atas, kata numpak merupakan bentuk sosiolek yang ada dalam novel Megamendung Kembar. Karena kata numpak tersebut memiliki arti khusus bagi pengendara becak dan si penumpang becak. Numpak dalam lingkup kelompok sosial yang ada dalam novel Megamendung Kembar memiliki arti menaiki. Oleh karenanya, kata numpak merupakan sebuah ciri khusus yang dimiliki kelompok sosial tersebut. Data berikut, merupakan data kata lain yang ada dalam novel Megamendung Kembar.

Data 02

“Ah, sekarang kan bukan musim lebaran, liburan, atau apa. Kok dibilang mrema?”(MK:24)

Berdasarkan kutipan di atas, kata mrema merupakan kata yang memiliki arti banyak permintaan, kata tersebut lahir dari mulut tukang becak ketika sedang mengangkut penumpang yaitu tokoh Awie. Berdasarkan analisa penulis, kata mrema di atas merupakan kata yang menjadi identitas kelompok. Oleh karenanya tidak semua orang mengerti arti dari kata mrema. Karena kata mrema itu sendiri merupakan suatu kata yang hanya dimengerti oleh orang-orang pada kelompok tersebut. Data berikutnya merupakan data bentuk kata yang ada dalam novel Megamendung Kembar, berikut data kutipannya.

Data 03 
“Salah satu acara jalan-jalan yang paling mengesankan adalah, saat mengunjungi Muludan”(MK:25)

Berdasarkan data pada kutipan di atas, kata muludan merupakan kata yang digunakan oleh kelompok sosial yang ada pada novel Megamendung Kembar sebagai bentuk perayaan yang dilakukan oleh kelompok yang ada dalam novel tersebut. Kata muludan merupakan bentuk perwujudan dari kata milad yang berarti memperingati, karena adanya kearifan lokal, bahasa dan budaya setempat. Maka muludan tersebut menjadi ritual keagamaan yang dilakukan oleh agama tertentu. Data berikutnya, merupakan data kata yang ada dalam novel Megamendung Kembar, berikut data kutipannya.

Data 04

"Sedang ransel yang sejak tadi menggandulinya selama mondar mandir, diturunkan dan diletakannya di dekat tumpukan kanco"(MK:34)

Berdasarkan data yang ada pada kutipan di atas, kanco merupakan bentuk kata

yang memiliki arti khusus yang hanya dimengerti oleh kelompok sosial yang ada dalam novel tersebut. Kata kanco juga memiliki arti dudukan kayu yang mana berfungsi sebagai tempat untuk membentangkan kain mori saat sedang dibatik. Kanco tersebut digunakan oleh tokoh Awie sebagai tempat untuk meletakkan ranselnya. Kata kanco juga menjadi sebuah ciri adanya sosiolek dalam novel tersebut. Data berikutnya merupakan bentuk kata lain yang ada dalam novel Megamendung Kembar.

Data 05

"Jadi jika semuanya dibuka, gudang ini akan terang benderang dan sejuk oleh angina yang dihantarkan pohon sukun, duwet"(MK:36)

Berdasarkan data pada kutipan di atas, kata duwet merupakan kata benda yang berarti buah jamblang. Duwet juga merupakan sebuah ciri khusus yang hanya dipahami oleh orang-orang yang ada pada kelompok tersebut. Kata duwet juga merupakan perwujudan dari sosiolek yang ada dalam novel Megamendung Kembar. Data selanjutnya, merupakan data kata lain yang ada dalam novel Megamendung Kembar, berikut datanya.

Data 06

“Masih banyak yang menyapa ramah dan mengantarkan aneka jaburan jika dia datang”(MK:39)

Berdasarkan data yang ada pada kutipan di atas, kata jaburan merupakan kata benda yang memiliki arti jajanan seperti camilan. Jaburan merupakan bentuk identitas yang ada dalam kelompok tersebut untuk berkomunikasi satu sama lain. Kata jaburan ini memiliki unsur sosiolek di dalamnya, karena tidak semua orang mengerti apa itu jaburan dan apa fungsi dari jaburan itu sendiri. Berikut ini merupakan bentuk lain dari kata yang ada dalam novel Megamendung Kembar, berikut data kutipannya.

Data 07

"Iyalah, Embah tahu. Setiap hari kamu kan sukanya baju kaus begini. Lalu, celana lepis atau celana pendek. Pakai rok batik, apalagi tapih"(MK:40) 
Berdasarkan data yang diperoleh dari kutipan di atas, kata tapih merupakan kata benda yang berarti kain jarit yang disandingkan dengan kebaya. Kata tapih juga merupakan suatu perwujudan adanya dialek sosial atau sosiolek di dalamnya. Tapih memiliki fungsi sebagai kain yang digunakan untuk acara formal yang dilakukan oleh kelompok tersebut. tapih diucapkan dari mulut si Embah kepada Awie karena lantaran cucunya si Embah itu yang tidak ingin memakai pakaian yang terlalu ribet, kata tapih itu keluar sebagai bentuk komunikasi antara si Embah dengan Awie. Data berikutnya merupakan data yang berupa kata lain yang ada dalam novel Megamendung Kembar.

Data 08

"Menghasilkan rasa dan aroma gurih yang tak membuat enek. Kerak bawahnya yang garing kemprik"(MK:49)

Berdasarkan data yang diperoleh dari kutipan di atas. Kemprik merupakan bentuk kata yang memiliki arti renyah atau garing layaknya sebuah kerupuk. Kemprik merupakan kata yang memiliki unsur sosiolek di dalamnya, karena kata itu hanya ada dan dimengerti oleh kelompok yang ada dalam novel tersebut. Kemprik juga menjadi kata yang digunakan untuk berkomunikasi antara satu orang maupun orang lainnya sehingga itu menjadi identitas kelompok. Data selanjutnya yaitu data kata lainnya yang ada dalam novel Megamendung Kembar. Berikut data kutipannya.

Data 09

"Ari aslie blesak sih, bagen dilap satus kali get ya tetep bae blesak Mbak"(MK:58)

Berdasarkan data yang diperoleh dari kutipan di atas. Kata yang penulis garis bawahi adalah kata bagen. Kata tersebut merupakan suatu kata yang dapat mewakili suatu ras tau kelompok tertentu. Bagen merupakan kata yang memiliki arti biar atau biarin. Kata ini hadir sebagai bentuk komunikasi yang jauh lebih santai antara individu ataupun kelompok. Kata bagen itu diucapkan Mbak Tum ketika sedang mengobrol dengan Awie karena tokoh Awie yang meledek wajah pembantunya itu yang sedang berlumuran minyak dan hitam. Data selanjutnya merupakan data kata yang memiliki arti lain yang ada dalam novel Megamendung Kembar. Berikut kutipan datanya.

Data 10

"Awie sudah selesai sarapan nasi lengko buatan Mbak Tum dan menghabiskan segelas air tawar ketika Is datang dengan sepeda ontel bapaknya"(MK:67)

Berdasarkan data yang diperoleh dari kutipan di atas. Lengko memiliki arti nasi putih yang diberi irisan tempe dan tahu, cacahan timun, tauge, rajangan daun kucai lalu disiram kecap manis. lengko juga adalah makanan khas kelompok yang ada dalam novel tersebut. Lengko dikonsumsi oleh Awie karena memang makanan tersebut sering dikonsumsi dirinya untuk sarapan pagi.

FRASA

Data 01

"Sinur mendekati meja makan yang diletakkan menempel pada dinding teras. Nasi dan lauk gesek"(MK:92) 
Berdasarkan data yang penulis peroleh dari kutipan di atas, frasa lauk gesek merupakan frasa benda. Frasa tersebut memiliki arti lauk ikan asin. Berdasarkan frasa pada data di atas, penulis menganalisis bahwasannya frasa di atas menjadi identitas sosial yang mana, frasa lauk gesek merupakan frasa yang menginformasikan jenis makanan yang tokoh Sinur makan. Frasa ini juga menjadi ciri kelompok sosial yang ada dalam novel Megamendung Kembar. Data selanjutnya yaitu data frasa lainnya yang ada dalam novel Megamendung Kembar, berikut data kutipannya.

Data 02

“Den Musa sudah membuatnya merasa gemetar karena deg-degan! Duh, Gusti Pangeran.. blaik iki”(MK:99) Berdasarkan data yang penulis peroleh dari kutipan di atas, data tersebut yaitu blaik iki, yang berarti celaka ini. data tersebut menurut penulis merupakan data berbentuk frasa. Frasa tersebut hanya dapat diketahui oleh kelompok sosial yang ada dalam novel Megamendung Kembar, frasa tersebut juga menjadi ciri dari identitas kelompok. Karena bahasa yang digunakannya dalam berkomunikasi berbeda dengan bahasa yang lain. Data berikutnya yaitu frasa lain yang ada dalam novel Megamendung Kembar, berikut data kutipannya.

Data 03

"Beberapa pabrik batik milik pengusaha Cina sudah tutup, pemiliknya menyingkir ke kota Cirebon. Karena tak tahan diganggung gerombolan Karimuda"(MK:100)

Berdasarkan data yang diperoleh dari kutipan di atas. Data yang diperoleh berupa frasa, data tersebut yaitu gerombolan Karimuda. Gerombolan Karimuda merupakan kelompok pemberontak yang ada dalam novel Megamendung Kembar yang paling anti dengan orang-orang Cina, gerombolam Karimuda ini terdengar sangat ganas. Gerombolan Karimuda merupakan suatu identitas yang dimiliki oleh kelompok yang ada dalam novel Megamendung Kembar. Tak semua orang mengenal siapa itu gerombolan Karimuda dan seperti apa pergerakan mereka. Data berikutnya yaitu data lain yang memiliki frasa di dalam novel Megamendung Kembar, berikut kutipannya.

Data 04

"Hari ini Sinur memang tidak berangkat dan pulang kerja naik sepeda dengan Bapak. Bapak sedang meriang Manastis"(MK:101)

Berdasarkan data yang penulis dapat dari kutipan di atas. Data tersebut merupakan data yang berbentuk frasa. Yaitu, meriang manastis. Frasa tersebut memiliki arti meriang panas-dingin. Frasa tersebut menjadi sebuah identitas kelompok, karena frasa di atas digunakan untuk berkomunikasi antara individu atau kelompok pada novel Megamendung Kembar. Data berikutnya merupakan data frasa lainnya yang ada dalam novel Megamendung Kembar.

Data 05

"Dengan berjalan kaki, Sinur perlu waktu cukup lama untuk sampai rumah. Sebab jarak tempuh Trusmi menuju Kalitengah cukup jauh juga. Berjalan sendirian melewati toang”(MK:101) 
Berdasarkan data yang diperoleh dari kutipan di atas. Frasa melewati toang merupakan frasa yang memiliki arti melewati kebun kosong, dari frasa tersebut penulis berpendapat bahwasannya frasa tersebut menjadi salah satu unsur pembangun sosiolek yang ada dalam novel Megamendung Kembar. Karena tak ada orang lain yang tau selain daripada kelompok yang ada dalam novel tersebut. Berikutnya yaitu data frasa lainnya yang ada pada novel Megamendung Kembar.

Data 06

“Kang, cepatlah bawa Sinur ke Pak Lebe. Ijab Kabul, jangan sampai getun”(MK:103)

Berdasarkan data yang ada pada kutipan di atas. Frasa Pak Lebe merupakan frasa yang memiliki arti Bapak Penghulu. Karena gurauan tokoh Untung kepada Kang Lanang yang menyukai Sinur. Frasa Pak Lebe digunakan sebagai bentuk komunikasi antar kelompok pada novel tersebut, frasa ini merupakan ciri yang ada dalam kelompok yang ada di dalam novel Megamendung Kembar. Data berikutnya yaitu frasa lain yang ada dalam novel Megamendung Kembar, berikut kutipan datanya.

Data 07

"Mereka sudah sampai pertelon. Teman-teman yang lain berjalan terus lurus. Hanya Sinur yang belok kiri”(MK:104)

Berdasarkan data yang ada pada kutipan di atas. Sampai pertelon memiliki arti sampai simpang tiga. Frasa tersebut digunakan untuk menginformasikan bahwasannya Sinur memiliki arah yang berbeda dari teman-temannya. Frasa di atas juga merupakan suatu identitas yang dimiliki oleh kelompok di dalam novel. Selain fungsinya untuk menginformasikan, simpang pertelon juga merupakan perwujudan adanya sosiolek di dalam novel tersebut. Data berikutnya yaitu frasa lainnya yang ada dalam novel Megamendung Kembar, berikut data kutipannya.

Data 08

"Seperti diiringi gemerincing genjring. Sinur menggerakkan kakinya dengan lincah. Antara berjalan dan berlari”(MK:106)

Berdasarkan data yang diperoleh dari kutipan di atas. Frasa gemerincing genjring merupakan frasa yang memiliki arti suara rebana. Rebana adalah alat musik yang digunakan untuk sebuah ritual rutinan seperti acara muludan, dalam frasa tersebut dapat dilihat bahwasannya frasa tersebut memiliki unsur sosiolek di dalamnya. Karena tidak semua orang mengetahui apa itu gemerincing genjiring dan bagaimana memainkannya. Data berikutnya yaitu frasa lain yang ada dalam novel Megamendung Kembar, berikut data kutipannya.

Data 09

“Merentangkan tangan, meloncat-loncat, sambil pacak gulu ke sana kemari”(MK:106)

Berdasarkan data yang ada pada kutipan di atas. Pacak gulu, merupakan suatu bentuk tarian pada leher dan kepala. Pacak gulu ini adalah jenis tarian yang ada dalam novel Megamendung Kembar. Selain fungsinya sebagai untuk kesenian. Pacak gulu juga merupakan perwujudan dari adanya sebuah sosiolek di 
dalam novel Megamendung Kembar. Karena, tidak semua orang mengetahui apa itu pacak gulu dan bagaimana fungsinya. Data berikutnya merupakan data frasa lainnya yang ada dalam novel Megamendung Kembar, berikut kutipan datanya.

Data 10

“Terima kasih, Den. Tapi maaf.... Tidak usah. Kula mlampah mawon. Sampun Carek”(MK:107)

Berdasarkan data yang ada pada kutipan di atas. Frasa sampun carek merupakan frasa yang memiliki arti sudah dekat, frasa ini digunakan tokoh Sinur ketika sedang berkomunikasi dengan majikannya yaitu Den Musa. Frasa ini selain digunakan untuk berkomunikasi, juga sebagai bentuk penolakan secara halus. frasa ini merupakan perwujudan dari adanya sosiolek di dalam novel Megamendung Kembar.

\section{KLAUSA}

Data 01

“Sinur ternganga, Kula boten ngibrit jeh, Den”(MK:108)

Berdasarkan data yang ada pada kutipan di atas. Penulis menyimpulkan bahwasannya klausa di atas memiliki arti, saya tidak lari. Klausa di atas digunakan Tokoh Sinur ketika sedang berbicara dengan Tokoh Den Musa, klausa Kula boten ngibrit keluar karena ketakutan Sinur bertemu dengan Den Musa. Klausa Kula boten ngibrit merupakan ciri identitas sosial yang dimiliki oleh Tokoh yang ada pada novel Megamendung Kembar. Klausa di atas menjadi suatu ciri pada kelompok itu. Data klausa lainnya ada pada kutipan berikut.

Data 02

"Kecuali sira wis ana sing mboyong, melu laki. Kalu sudah begitu, baru Emak tak bisa lagi ngatur-ngatur sira"(MK:113)

Berdasarkan data pada kutipan di atas. Penulis menyimpulkan bahwasannya klausa sira wis ana sing mboyong. Merupakan sebuah ciri untuk identitas sosial yang dimiliki kelompok tersebut, dan klausa sira wis ana sing mboyong juga merupakan perwujudan dari bentuk sosiolek yang ada dalam novel Megamendung Kembar. Klausa tersebut memiliki arti kamu sudah ada yang membawa, Klausa itu diutarakan Emak karena Sinur yang terus merengek kepada Emak mengenai dirinya yang ingin berhenti membatik di pabrik Den Musa. Data berikutnya merupakan klausa lain yang ada dalam novel Megamendung Kembar, berikut data kutipannya.

\section{Data 03}

"Mang Suma, morinya sudah habis ini. Harus nguleni lagi, lapor Sinur kepada Mang Suma buruh ngulen"(MK:116)

Berdasarkan data pada kutipan di atas. Penulis menyimpulkan, bahwasannya klausa Mang Suma buruh ngulen, merupakan klausa yang menjadi sebuah ciri sosial atau identitas sosial yang ada dalam novel Megamendung Kembar. Klausa Mang Suma buruh ngulen merupakan perwujudan dari sosiolek yang ada dalam novel Megamendung Kembar, klausa Mang Suma buruh ngulen juga memiliki arti Mang Suma buruh 
membersihkan mori baru yang baru dari kanji. Data berikutnya merupakan klausa lainnya yang ada dalam novel Megamendung Kembar, berikut data kutipannya.

Data 04

“Apa keadaan sudah benar-benar parah? Tanya Untung si tukang ngetel, jangan membuat deg-degan, Mang"(MK:117)

Berdasarkan dari data pada kutipan di atas. Penulis menyimpulkan bahwasannya klausa Untung si tukang ngetel, merupakan suatu klausa yang digunakan oleh orang-orang yang ada pada kelompok tersebut untuk memanggil Untung dengan julukannya. Klausa Untung si tukang ngetel memiliki arti Untung si tukang mengikis malam yang telah digunakan, dikumpulkan kemudian dicairkan sehingga dapat digunakan kembali. Klausa Untung si tukang ngetel merupakan bentuk perwujudan dari sosiolek yang ada dalam novel Megamendung Kembar. Data berikutnya merupakan bentuk klausa lainnya yang ada dalam novel Megamendung Kembar, berikut kutipannya.

\section{Data 05}

"Aku punya firasat buruk. Sepertinya pabrik memang mau tutup. Den Musa dan Den Yahya tidak keluar rumah dari pagi. Den Hayu dan Den Menis juga mingslep"(MK:121)

Berdasarkan data pada kutipan di atas, penulis menyimpulkan bahwasannya. Klausa Den Hayu dan Den Menis juga mingslep merupakan klausa yang digunakan oleh pegawai pabrik batik yang sedang risau melihat keadaan pabriknya yang sedang menurun. Klausa Den Hayu dan Den Menis juga mingslep memiliki arti tak menampakkan diri, klausa ini juga menjadi sebuah peruwujudan dari sosiolek yang ada dalam novel Megamendung Kembar. Data berikutnya merupakan klausa lain yang ada dalam novel Megamendung Kembar.

Data 06

“Apa kata Emak dan Bapak nanti? Apa kata Eha? Apa kata keluarga besar Pak Kadari? Apa kata temantemannya? Semuanya sungguh memalukan untuk dibayangkan. Duh, Emak-Bapak nyuwun pangapura"(MK:136)

Berdasarkan data yang ada pada kutipan di atas. Penulis menyimpulkan bahwasannya klausa EmakBapak nyuwun pangapura merupakan klausa yang digunakan oleh Sinur untuk mengimajinasikan apabila hal yang tidak diinginkan terjadi terlebih kepada Emak dan Bapaknya. Klausa Emak-Bapak nyuwun pangapura memiliki arti mohon maaf, dari klausa tersebut penulis menyimpulkan bahwasannya klausa Emak-Bapak nyuwun pangapura merupakan perwujudan bentuk sosiolek yang ada dalam novel Megamendung Kembar. Berikut data klausa lainnya yang ada dalam novel Megamendung Kembar.

Data 07

"Padahal biasanya Emak itu paling cerewet soal adab mengambil air di kali. Anak-anaknya sampai bungeng"(MK:169) 
Berdasarkan data pada kutipan di atas. Penulis menyimpulkan bahwasannya klausa Anak-anaknya sampai bungeng merupakan klausa yang digunakan oleh tokoh Sinur untuk mengingatkan dirinya akan nasehat Emak, klausa tersebut teringat karena seringnya Emak menasehati Sinur tentang adab mengambil air di kali, klausa di atas memiliki arti berdengung seperti bising. Klausa Anak-anaknya sampai bungeng merupakan bentuk perwujudan dari sosiolek yang ada dalam novel Megamendung Kembar. Berikut data klausa lainnya yang ada dalam novel Megamendung Kembar.

Data 08

"Kula mboten ngertos, Pak. Nyuwun pangapura. Kula pamit. Pak Kadari mendengus, tak mendesak lebih jauh"(MK:181)

Berdasarkan data pada kutipan di atas. Klausa Kula mboten ngertos merupakan klausa yang digunakan Sinur untuk berdialog dengan Pak Kadari, klausa tersebut digunakan untuk menginformasikan bahwasannya dia tidak tahu apa-apa. Klausa Kula mboten ngertos memiliki arti Aku tidak mengerti. Klausa tersebut merupakan bentuk perwujudan dari sosiolek yang ada dalam novel Megamendung Kembar, karena itu menjadi ciri bagi identitas kelompok tersebut. Data berikutnya merupakan data klausa lainnya yang ada dalam novel Megamendung Kembar, berikut data kutipannya.

Data 09

"Tadi pagi-pagi sekali, Wak Sumi membawakan geblog. Sangat mungkin dia membawakan berita-berita memalukan itu"(MK:187)

Berdasarkan data pada kutipan di atas. Penulis menyimpulkan bahwasannya klausa Wak Sumi membawakan geblog, merupakan klausa yang digunakan Sinur untuk beropini mengenai kabar tentang kedekatannya dengan Den Musa. Klausa Wak Sumi membawakan geblog merupakan klausa yang memiliki arti Wak Sumi membawakan kudapan, makanan seperti singkong rebus yang ditaburi parutan kelapa. Klausa Wak Sumi membawakan geblog merupakan bentuk perwujudan dari sosiolek yang ada dalam novel Megamendung Kembar. Berikutnya data klausa lainnya yang ada dalam novel

Megamendung Kembar, berikut data kutipannya.

Data 10

"Kadang-kadang dia datang untuk menukar hasil kebunnya dengan klobot-bako atau beras. Sudah berharihari mereka hanya makan boled"(MK:188)

Berdasarkan data pada kutipan di atas. Penulis menyimpulkan bahwasannya klausa mereka hanya makan boled merupakan klausa yang digunakan oleh kelompok tersebut dalam bertahan hidup ketika Trusmi dan Kalitengah sedang sangat susah atau krisis. Klausa mereka hanya makan boled memiliki arti mereka hanya makan ubi, dari klausa tersebut penulis menyimpulkan bahwasannya klausa mereka hanya makan boled merupakan perwujudan dari sosiolek yang ada dalam novel Megamendung Kembar.

FUNGSI SOSIOLEK DALAM NOVEL MEGAMENDUNG KEMBAR 
Penulis menjabarkan beberapa fungsi sosiolek yang ada dalam novel Megamendung Kembar karya Retni S.B diantaranya fungsi informatif, fungsi direktif dan fungsi ekspresif.

\section{FUNGSI INFORMATIF}

Data 01

"Sinur menunduk. Memandangi jatah setengah piring nasi parak dan secuil gesek pethek di hadapannya. Sudah sejak semalam dia menimbang-nimbang akan membicarakan soal ini dengan bapak emaknya"(MK:111)

Berdasarkan kata yang didapat oleh penulis melalui kutipan yang ada dalam novel Megamendung Kembar. Penulis menjabarkan fungsi sosiolek yang ada pada data di atas. Tokoh Sinur atau Embah yang ada pada data 01

Ingin menyampaikan sebuah informasi kepada bapak dan ibunya, yaitu berupa kegelisahan dan ketidaktenangan hatinya, bahwasannya ia ingin berhenti kerja dari pabrik batik pak Kadari. Hal tersebut dilihat pada "Sudah sejak semalam dia akan membicarakan soal ini dengan bapak emaknya, dari pernyataan tersebut dapat diketahui bahwasannya tokoh Sinur resah dan gundah dengan segala problematika yang ia alami di pabrik pak Kadari. Ia ingin menyampaikan beberapa informasi mengenai dirinya yang ingin berhenti bekerja, sedangkan unsur sosiolek menurut penulis yang ada dalam percakapan tersebut adalah berupa perak dan gesek pethek, perak berarti dalam bahasa Cirebon berupa nasi yang tidak pulen karena murah harganya. Sedangkan pethek merupakan ikan asin yang bentuknya pipih. Dari kedua simbol itu penulis berpendapat bahwasannya dua hal tersebut menggambarkan situasi ekonomi keluarga Sinur atau keluarga si Embah. Fungsi informatif yang kedua dapat kita lihat dalam kutipan berikut.

\section{Data 02}

"kain morinya belum ada lagi, Nok. Kata Pak Jaja, pesanan belum dikirim moga-moga saja Den Musa bisa cepat mengusahakan. Pabrik bisa tutup kalau mori dan pewarna terus-terusan susah dicari”(MK:117)

Kutipan berikut yang ada pada data 02, penulis mengidentifikasi bahwasannya data tersebut memiliki fungsi informatif sosiolek di dalamnya, hal tersebut dapat dibuktikan dengan perkataan pak Jaja pada kalimat awal yang ingin menginformasikan bahwasannya kain morinya belum ada lagi. Hal tersebut disampaikan kepada para buruh pabrik yang bekerja di pabrik pak Kadiri, sedangkan unsur sosiolek yang ada dalam kutipan tersebut adalah berupa kata mori, Den, pewarna dan pabrik. Dari keempat kata tersebut penulis mengambil kesimpulan bahwasannya keempat kata tersebut merupakan hal yang bersinggungan dengan profesi seseorang dan tingkat kebangsawanan seseorang. Fungsi informatif yang selanjutnya ada pada kutipan berikut.

Data 03

"Sebab pekerjaan ngerengreng adalah pekerjaan individu. Tak bisa bersama-sama atau bergantian. Bisa kacau dan tak seirama jika motif batik ditulis oleh tangan yang berbeda-beda. Ini bukan kepandaian biasa"(MK:121) 
Berdasarkan data di atas penulis akan mengidentifikasi bahwasannya terdapat fungsi informatif, dari data 03 di atas dijelaskan hanya Sinur saja yang dapat ngarengreng atau menyusun pola awal ketika seseorang ingin membuat batik, informasi tersebut disampaikan oleh buruh pabrik yang bingung karena hampir diphk. Sedangkan unsur sosiolek yang ada dalam data 03 di atas yaitu pada kata ngarengreng dan motif. Dua kata tersebut secara tidak langsung menggambarkan pekerjaan seorang pembatik ketika ingin memulai pekerjaannya. Seirama dengan syarat mutlak sosiolek yaitu berupa menggambar atau melihat batasanbatasan sosial, taraf ekonomi dan profesi seseorang melalui bahasa yang digunakan oleh orang tersebut.

\section{FUNGSI EKSPRESIF}

Data 01

“Mataku pedes, Mak. Tak kuat lama-lama ndamu malam panas"(MK:112)

Berdasarkan data yang penulis dapat dari novel Megamendung Kembar melalui kutipan di atas, penulis ingin mengidentifikasi kutipan yang ada pada data 01. Dari data yang diperoleh oleh penulis, Sinur ingin menyampaikan ekspresi

jiwanya dan perasaanya melalui dialog di atas ke pada sang Emak. Walau Sinur berbohong pada dialog di atas, hal tersebut semata-mata hanya ingin keinginannya terpenuhi. Yaitu, berhenti bekerja dari pabrik batik pak Kadari. Sedangkan unsur sosiolek yang ada dalam kutipan di atas yaitu berupa malam panas dan ndamu, dari dua kata di atas penulis berpendapat bahwasannya hal tersebut yang menjadi unsur sosiolek di dalam data tersebut, karena malam adalah lilin yang dicairkan untuk membatik dan ndamu adalah bahasa Cirebon yang artinya meniup. Dari dua kata tersebut bisa mewakili posisi Sinur sebagai apa dan pekerjaannya. Fungsi ekspresif selanjutnya dapat dilihat dari kutipan berikut.

\section{Data 02}

"Pedes bagaimana si Nur? Kenapa mendadak jadi pedes? Dulu-dulu kok tak apa-apa? Emak baru dengar malam panas bisa membuat pedes mata, malamne digrujugnang ning mata tah priben? Jangan macammacam ya, Nur!"(MK:112)

Dari data di atas penulis menyimpulkan bahwasannya Emak Sinur ingin menyampaikan ekspresi jiwanya yang berupa penolakan kepada Sinur yang ingin berhenti bekerja sebagai buruh batik di pabrik Pak Kadari. Hal tersebut diungkapkan dalam kalimat terakhir yang berbahasa jawa dengan arti malamnya disiramkan ke mata atau bagaimana? Hal tersebut merupakan luapan emosi Emak yang disampaikan melalui fungsi ekspresif pada pembahasan ini, sedangkan unsur sosioleknya yaitu berupa malam panas yang berarti lilin yang dicarikan yang digunakan oleh pembatik untuk membatik. Fungsi ekspresif selanjutnya dapat dilihat dalam kutipan berikut.

Data 03

"Hayu itu istri pilihanku sendiri, Nur. Sudah pasti aku sayang kepadanya. Sudah tanggung jawabku untuk membuatnya senang dan tenteram. Sudah

menjadi kewajibanku untuk menjaganya sampai mati. Jadi aku tahu di mana salahnya, sampai aku menyadari bahwa aku juga suka kepadamu.(MK:132-133) 
Dari kutipan di atas penulis berpendapat bahwasannya terdapat fungsi ekspresif pada kutipan tersebut, yang mana tokoh Den Musa yang sudah beristri mengungkapkan emosinya, ekspresi jiwanya kepada Sinur buruh batik ditempatnya. Adapun hal Den Musa merupakan seorang yang sudah beristri ia sudah menginformasikannya dan Sinur pun sudah tahu mengenai hal itu, unsur sosiolek di dalam percakapan antara Sinur dan Den Musa adalah terletak pada saat Den Musa menyampaikan perasaannya ke pada Sinur, kata Den itu sendiri pun sebenarnya sudah mewakili dan menjelaskan siapa dirinya di tambah batasan sosial antara posisi Den Musa sebagai pemberi kerja dan Sinur sebagai buruh atau pekerja di pabrik pak Kadari.

\section{FUNGSI DIREKTIF}

Data 01

"Aku mau berhenti kerja di pabrik, Mak. Ulang sinur takut-takut. Sebab mulut emaknya ini luar biasa tajam dan tangannya gembar mencubit sampai biru"(MK:112)

Berdasarkan data yang penulis peroleh dari novel Megamendung Kembar, pada kutipan data di atas penulis mengidentifikasi bahwasannya ada fungsi direktif antara tokoh Sinur dan Emak. Yang mana, Sinur ingin membujuk Emak agar menerima permintaannya untuk berhenti bekerja di pabrik batik pak Kadari, hal itu dibuktikan pada awal kalimat bujukan Sinur, yang mengajak emak agar menerima permohonannya, walau ia sendiri tahu apa akibat dari kata-kata yang ia ucapkan. Sedangkan itu, unsur sosiolek yang ada di dalam kutipan di atas juga terdapat pada kalimat awal mengenai bujukan Sinur untuk berhenti kerja di pabrik, kata pabrik itu sendiri menunjukan identitas Sinur dan status sosial Sinur di masyarakat. Fungsi direktif lain yang ada dalam novel Megamendung Kembar dapat dilihat dari kutipan berikut:

Data 02

"Kalau begitu, ngomongnya yang bagus-bagus saja. Moga-moga karimuda minggat, Jepang ludes, Belanda kapok, kampung aman, pabrik lancar, batik laris, upah naik."(MK:121)

Berdasarkan data pada kutipan di atas penulis berpendapat bahwasannya pada data di atas terdapat fungsi direktif dalam penggunannya, hal tersebut dapat dilihat dari rampaian doa yang dirampai Sinur kepada tokoh Eha yaitu berupa ajakan untuk mengucap yang baik-baik dan jangan bicara yang buruk-buruk hal tersebut membuktikan adanya fungsi direktif di dalam percakapan tersebut. Hal lainnya seperti unsur sosiolek di dalamnya dapat dilihat pada bait terakhir ajakan/doanya pabrik lancar, batik laris, upah naik. Hal tersebut secara gamblang dijelaskan mengenai golongan sosial tokoh tersebut di masyarakat, dan cukup untuk menjadi syarat utama sebuah sosiolek. Fungsi direktif yang ketiga terdapat pada pernyataan berikut ini.

Data 03

"Aku antar pulang. Karimuda sedang ngamuk. Karimuda? Itukah sumber suara riuh tadi? Bukan pertengkaran Den Musa dan Den Hayu ?" (MK:138)

Dari data yang dijabarkan pada kutipan di atas data tersebut menjelaskan bahwasannya ada fungsi direktif di dalamnya, hal tersebut dapat dilihat dari ajakan atau bujukan kang Lanang ketika ingin mengantar Sinur pergi pulang 
ke rumahnya, hal tersebut sudah cukup untuk menjelaskan adanya fungsi direktif di dalam kutipan di atas. Hal lainnya seperti unsur sosiolek di dalam kutipan di atas dapat dilihat dari pertengkaran Den Musa dan Den Hayu, kendati pertengkaran tersebut dipicu oleh Sinur, namun kata Den dan Karimuda menjelaskan golongan sosial antara dua belah kubu di atas, Den yaitu orang-orang tinggi yang memberi kerjaan. Sedang Karimuda adalah sekelompok masyarakat yang menjarahi orang-orang yang diduga ada main dengan Jepang ataupun Belanda. Penulis berpendapat bahwasannya dari kedua kata di atas cukup menjadi syarat sebuah sosiolek.

\section{KESIMPULAN DAN SARAN}

Sosiolek atau dialek sosial sebagai sebuah identitas yang dimiliki oleh kelompok sosial tertentu menjadi suatu kajian yang sangat menarik untuk diteliti, karena melalui sosiolek yang ada dalam novel Megamendung Kembar karya Retni S.B penulis mendapatkan berbagai macam informasi mengenai sosiolek atau fungsi sosiolek itu di dalam novel, dari data-data yang penulis dapatkan dari kutipan-kutipan yang diambil, penulis menyadari bahwasannya sosiolek atau dialek sosial menjadi sebuah seni berbahasa yang mana memiliki fungsi untuk membaca jarak sosial seseorang di masyarakat. Adapaun hal-hal yang penulis dapatkan dari penelitian ini ialah.

Pertama, berdasarkan data yang penulis temukan dalam setiap peristiwa yang ada dalam novel Megamendung Kembar. Penulis mendapatkan beberapa data berupa bentuk lingual sosiolek yang ada dalam novel Megamendung Kembar, diantara data itu berupa. 10 data berbentuk kata, 10 data berbentuk frasa dan 10 data berbentuk klausa.

Kedua, selain data yang berbentuk lingual, penulis juga menemukan beberapa data yang berupa fungsi sosiolek yang ada di dalam novel Megamendung Kembar. Fungsi ini meliputi fungsi informatif, fungsi ekspresif dan fungsi direktif. Adapun kuantitas temuan data fungsi di atas yaitu, 3 data fungsi informatif, 3 data fungsi ekspresif dan 3 data fungsi direktif.

\section{DAFTAR PUSTAKA}

Anggito, A., Setiawan, J. (2018). Metodologi Penelitian Kualitatif. Sukabumi: CV Jejak.

Chaer, A., Leoni, A. (2010). Sosiolinguistik Perkenalan Awal (Edisi Revisi). Indonesia Rineka Cipta.

Lapasau, M., E. Zaenal, A. (2016). Sosiolinguistik. Tangerang: Pustaka Mandiri.

S., B. Retni. (2016). Megamendung Kembar. Jakarta: PT. Gramedia Pustaka Utama

Warisman. (2014). Sosiolingustik Teori dan Aplikasi dalam Pembelajaran Malang: UB Press. 